\title{
ICTOPI
}

УДК 004.738.5:070+94:355](477.83)

DOI https://doi.org/10.24919/2308-4863/41-1-1

\author{
Nataliia VOVK, \\ orcid.org/0000-0002-2470-7188 \\ Candidate of Historical Sciences, Associate Professor, \\ Associate Professor at the Department of Social Communication and Information Activity \\ Lviv Politechnic National University \\ (Lviv, Ukraine) Nataliia.S.Vovk@lpnu.ua
}

\section{THE PRESS OF THE UKRAINIAN GALICIAN ARMY ON THE INTERNET: A COMPARATIVE ANALYSIS OF DIGITALIZED PUBLICATIONS}

The article reveals the importance of digitization of archival documents for modern Ukrainian society. Attention is paid to digitized periodicals of the Ukrainian Galician Army as a source of information about the establishment of a single conciliar state. Modern electronic archives and magazines of 1918-1919 are analyzed.

The topical issue today is the digitization of documents from the period of the Ukrainian National Revolution of 1917-1921. Restored freedom of the press and society's need for proper information have led to the emergence of a national information space aimed at the full implementation of the idea of Ukrainian statehood. Particular attention should be paid to digitization and open access to the media of the Western Ukrainian People's Republic (ZUNR). This determined the relevance of the study.

The article analyzes the state of digitization of the periodical magazine of the State Secretariat for Military Affairs "Vistnyk DSVS". In particular, the analysis of scanned copies of issues of the official "Bulletin", published in 2015 by the electronic archive of the liberation movement avrorg.ua.

The author also reviewed the repository of the site "Archive of old newspapers", which provides a digitized version of another newapaper "Strilets".

The article presents an analysis of the section "Ukrainian Galician Army" of the centralized repository for multimedia files of Wikimedia in more than 100 photos in different categories. In addition, the characteristics of separate collections of electronic exhibitions of archival funds of Ukraine are given. In particular, the analysis of the site of the Central Historical Archive of higher authorities and administration, which contains periodicals published in the Western Ukrainian People's Republic: "Ukraina", "Respublika" and "Visnyk derzhavnykh zakoniv ta pidzakonnykh aktiv zakhidnykh oblastei UNR". The State Archives of the Lviv Region (DALO) has a partial publication of periodicals of the Western Ukrainian People's Republic, which is available in the form of electronic exhibitions of documents.

Key words: Ukrainian Galician Army, Western Ukrainian People 's Republic, electronic archives, periodicals, digitized editions.

Наталія ВОВК,

orcid.org/0000-0002-2470-7188

кандидат історичних наук, дочент,

доиент кафедри соиіальних комунікаиій та інформаиійної діяльності Начіонального університету «Львівська політехніка»

(Львів, Украӥна) Nataliia.S.Vovk@lpnu.ua

\section{ПРЕСА УКРАЇНСЬКОЇ ГАЛИЦЬКОЇ АРМІЇ У МЕРЕЖІ ІНТЕРНЕТ: ПОРІВНЯЛЬНИЙ АНАЛІЗ ОЦИФРОВАНИХ ВИДАНЬ}

У статті розкрито значення оцифрування архівних документів для сучасного українського суспільства. Приділено увагу оцифрованим періодичним виданням Украӥнської галицької армії як джерелу інформації про встановлення єдиної соборної держави. Проаналізовані сучасні електронні архіви та часописи 1918-1919 років.

Актуальним питанням на сьогодні є оцифрування документів періоду Української національної революції 1917-1921 років. Відновлена свобода преси та потреба суспільства у належному інформуванні призвели до появи наиіонального інформаџійного простору, спрямованого на повне втілення ідеї української державності. Особливу увагу слід звернути на очифрування та відкритий доступ до ЗмІ Західноукраӥнської Народної Республіки (ЗУНР). Це зумовило актуальність дослідження. 
У статті проаналізовано стан оцифрування періодичного часопису Державного секретаріату військових справ - «Вісник ДСВС». Зокрема, наведено аналіз відсканованих копій номерів офіиійного «Вісника», опублікованих у 2015 р. електронним архівом визвольного руху avr.org.ua.

Авторка розглянула і сховище сайту «Архів старих газет», де подано оцифрований варіант ще одного журналу «Стрілець».

У статті представлено аналіз розділу «Українська Галищька Армія» изентралізованого сховища для мультимедійних файлів Вікімедіа у розміщено більше 100 фотографій у різних категоріях. Окрім того, подано характеристику окремих збірників електронних виставок архівних фондів Украйни. Зокрема представлений аналіз сайту Центрального історичного архіву вищих органів влади та управління, де розмімено періодичні випуски, які виходили в Західноукраїнській Народній Республічі: «Україна», «Республіка» та «Вісник державних законів та підзаконних актів західних областей УНР». У Державному архіві Львівської області (ДАЛО) наявна часткова публікаиія періодичних видань ЗУНР, яка доступна у вигляді електронних виставок документів.

Ключові слова: Українська галицька армія, Західноукраїнська народна республіка електронні архіви, періодична преса, очифровані видання.

Formulation of the problem. The issue of historical documents digitization and the creation of media archives in today's information society is extremely important. As a result of such activities, not only secondary analysis of documents by modern researchers becomes available to the public, but also primary documents: photographs, personal and official documents, the press, etc. Digitized historical document becomes a tool for influencing the public through free access to the original sources of Ukrainian statehood. The issue of documents digitization of the Ukrainian national revolution period (1917-1921) is relevant today. Despite its defeat, irreversible state aspirations and vast experience of achievements and failures of state building were laid down currently. The cardinal revolutionary transformations of this revolutionary epoch contributed to the awakening of national consciousness among the broadest layers of Ukrainian citizenship. It has also led to democratic progress in all spheres of public life. Restored freedom of the press and the need of society for proper information laid the preconditions for the formation of a national information space aimed at the full implementation of the idea of Ukrainian statehood.

Analysis research. Garanin O., Lobuzin I., Kosyak I. and others studied the documents digitization, including archival ones. In modern researches features of the sources new forms formation in the conditions of information technologies introduction are considered, the basic technological stages of digitization of archival documents, etc. are defined.

Today, digitized archival sources have become extremely widespread. Some international programs ("Memory of the World", 1992; "Charter on the Preservation of Digital Heritage", 2003; "Manifesto for Digital Libraries", 2010) have caused the creation of a huge number of educational digital resources, scientific, historical and cultural content (Lobuzin, 2012: 105).

The purpose of the article - to analyze the state of the Ukrainian Galician Army periodical press digitization.
Presenting main material. Digitization and open access to the press of the Western Ukrainian People's Republic (ZUNR) deserve special attention. ZUNR fought for its independence both through diplomatic actions and through the efforts of the Ukrainian Galician Army (UGA), which was formed as a regular armed force in extremely unfavorable military and political conditions and during the fighting of November 1918 - July 1919.

The information and press field of the Western Ukrainian People's Republic was mostly filled by civil and national organizations or government agencies. In its general majority, the press of the Western Ukrainian People's Republic had a non-partisan character and stood in the way of Ukrainian statehood (Vovk, 2016: 35).

Among the total number of magazines published in Western Ukraine, the military press of the UGA stands out. UGA military periodicals were divided into three groups: central authorities (Derzhavnyi sekretariat viiskovykh sprav (DSVS), Nachalna komanda Halytskoi armii (NKHA) - "Vistnyk Derzhavnoho Sekretariatu Viiskovykh Sprav", "Strilets", "Vistka"; corpus newspapers - "Kozatskyi holos" (1-st Corps), "Poleva hazeta" (2-d Corps), "Striletskyi shliakh" (3-d Corps); newapapers of brigades and battle groups - "USS»»"(1-st USS Brigade), "Schid" (battle group "Skhid") etc. (Vovk, 2016: 34).

An important stage in providing the army with informational, normative and legislative material was the publication of its own publication of DSVS "Vistnyk DCVS". The first issue of "Vistnyk" was published on December 1, 1918.

During the six months of its publication, "Vistnyk" published six dozen normative legal acts (regulations). Prime Ministers K. Levitsky and V. Golubovych, State Secretaries of Military Affairs signed most of them. The Minister of War signed some regulations and ministers of other interested agencies. In general, the documents published in "Vistnyk" concerned military-territorial administration, mobiliza- 
tion measures (demobilization, mobilization, conscription and release), military personnel, structural reorganization of troops, material support and social protection of personnel, military administration, military judiciary, gendarmerie, armaments and military ammunition, increase of military knowledge, organization of chaplaincy service, quartermaster and medical service, equestrian and veterinary service, protection, training and education (Tkachuk, 2009: 254).

"Vistnyk" was designed, first of all, for the officers of the army, it published orders and instructions on the services order, assignment of ranks, disciplinary practice of commanders. Only in one of its numbers the lists of appointments (about assignment of the highest ranks) about 1100 officers of infantry, artillery, cavalry, flying and other armies were printed (Vistnyk derzhavnykh zakoniv, 1919: 9). Undoubtedly, this publication was an important source not only of an informative nature, but first of all, a carrier of official documentary information of the UGA highest military body.

In 2015, the Electronic Archive of the Liberation Movement avr.org.ua published scanned copies of 16 issues of the official "Vistnyk" of the Ministry of War of the Western Ukrainian People's Republic for the period 01.12.1918-10.10.1919 (for 1918 - 3 issues, for $1919-13$ issues).

Electronic archive of the Ukrainian liberation movement - a striking example of a well-established program of Ukrainian archival funds informatization. Avr.org.ua - joint project of the Center for Liberation Movement Studies, Lviv National University named after I. Franko and the National Museum-Memorial to the Victims of Occupation Regimes "Lontsky Prison" (Vovk, 2016: 202).

Electronic versions of "Vistnyk DSVS" on the site are placed in the section "Ukrainian statehood of 1917-1921", where there are more than 500 digitized documents.

Based on the analysis of information about the viewing of "Vistnyk DSVS" in Fig. 1. quantitative characteristics of public interest in these electronic documents are given.

The chart shows that the first issues of the newspaper are the most popular among site visitors. In particular, "Vistnyk DSVS" of December 1, 1918 was downloaded 366 times (189 times in 2017) and viewed 437 times (264 times in 2017) (Vovk, 2016: 33). The fact of such popularity of this periodical first issue can be explained by two reasons:

- the first issue of the newspaper is relevant in connection with the placement in it of the oath of the Ukrainian troops of the Western Ukrainian People's Republic, the order on demobilization of troops on the territory of the Western Ukrainian People's Republic and other information on the establishment of the UGA;

- high number of views and downloads caused by the simple interest of site users.

Other numbers of "Vistnyk DSVS" are downloaded up to 100 times on average and viewed up to 50 times.

The first subgroup of UGA periodicals (central authorities) periodical of the Nachalna Komanda UGA "Strilets" (Bytysia chy myrytysia, 1919: 3). This newspaper published reports of the National Council, articles on the coverage of the army's military path, publications on historical topics and coverage of cultural life in Galicia. This newspaper was one of the most popular newspapers among the military, published by the famous poet and playwright Vasyl Pachovsky. The newspaper was published daily from January 1919 in a huge circulation - 16 thousand copies in Ternopil, Stanislavov, Stryi, Borshchiv, and from June 15, 1919 in Kamianets-Podilskyi as "Ukrainskyi strilets" (editor - G. Mykytei). The newspaper ceased to exist on November 16, 1919. (Vovk, 2016: 35) The first issue of the newspaper "Strilets" was published on January 1, 1919 in Ternopil (Bachynskyi, 1978, 132). The weekly, as a government newspaper, reported on the meetings of the National Council, articles on current topics, as well as news from the front.

This is digitized by the Archive of Old Newspapers - a site dedicated to old newspapers that have ever been published in Ukraine or are related to it (Archive of Old Newspapers). The site contains seven digitized periodicals of different years: "Visti VUTsVK", "Khliborob", "Strilets", "Dilo", "Shliakh do voli", "Pravda" and "Kyevskyi telehraf".

A total of 21 issues of the newspaper "Sagittarius" for 1919 are published on the Site of the Archive of Old Newspapers:

- for April - 3 issues;

- for May - 2 issues;

- for June - 1 issue;

- for July - 7 issues;

- for August - 3 issues;

- for October - 5 issues.

The digitized last issue of the newspaper "Strilets" (October 9, 1919) precedes the transfer of the UGA Initial Command to the Baltics, where instead of the newspaper "Strilets" another newspaper "Prolom" began to appear. (Vovk, 2016: 36).

Unlike the electronic version of the newspaper "Vistnyk Derzhavnoho Sekretariatu Viiskovykh Sprav", which is only scanned, the newspaper "Strilets" is presented in a different form: the user can 


\section{Quantity of downloads and views of the Vistnyk}

DSVS (August 2021)

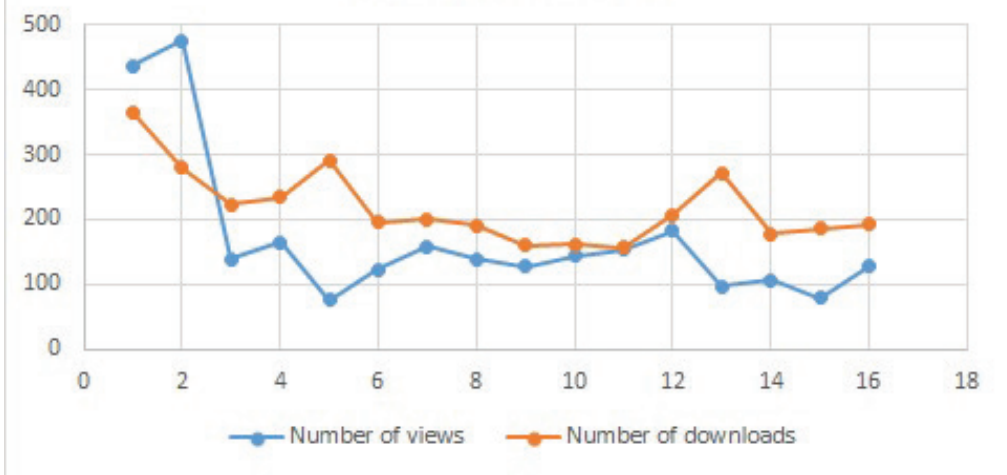

Fig. 1. Quantitative data of downloads and revisions of the "Vistnyk DSVS" (August 2021).

choose from the proposed menu (consisting of magazine pages), select the required section and article. This version of the old periodicals digitization greatly facilitates the work with the document and allows you to preserve the integrity of archival sources.

There are 172 photos in the following categories on the general centralized repository for media licenses provided by Wikimedia Commons in the Ukrainian Galician Army section:

- Chaplains of Ukrainian Galician Army - 30 photos;

- Mass grave of UGA soldiers in Berestechko|4 photos;

- Franz Xavier Bonne"- 2 photos;

- Chortkiv Offensive" - 7 photos;

- Colonels of Ukrainian Galician Army|- 3 photos;

- Generals of Ukrainian Galician Army|" 5 photos;

- Holos taboral- 3 photos;

- Mass grave of UGA pilots and UIA soldiers in Krasne'- 2 photos;

- Mykola Lahodynskyil- 2 photos;

- Severyn Leshchiy|-2 photos;

- Mass grave of UGA soldiers in Rohatyn"-2 photos;

- Mass graves of UGA soldiers in Yavoriv|" 2 photos;

- Military people of Ukrainian Galician Army|"2 photos;

- Military rank insignia of the Ukrainian Army (UGA 1919)"- 15 photos;

- Mykhailo Omelianovych-Pavlenko|- 6 photos;

- Evhen Pobihushchyil- 3 photos;

- Stefaniya Rybchak|- 1 photo;

- Sich Riflemen|-32 photos;

- Tomb of Dmytro Dychkevych - 5 photos;
- Tomb of Volodymyr Skybinskyil-4 photos;

- Ukrainian Sich Riflemen|- 36 photos;

- Vilna Ukrainal-4 photos.

Compared to 2017, the number of photos on the resource has increased by almost 100 units (Vovk, 2016: 35). Such dynamics of renewal testifies to public interest in this subject. Most of the photos posted on Wikimedia Commons are digitized (scanned, photographed) photos from the periodicals of the time.

This personalized approach to digitizing information allows not only to identify members of the Ukrainian Galician Army, but also to carry out a photographic comparative analysis of the modern army and the armed forces of the UGA.

Central State Archive of Supreme Bodies of Power and Government of Ukraine (TSDAVO of Ukraine) preserves documentary evidence of the activities of all power structures that functioned in Ukraine during the twentieth century (Tkachuk, 2009: 295). Periodicals published on the territory of the Western Ukrainian People's Republic are placed in separate collections of electronic exhibitions. In particular, in the exhibition "To the Day of the Unification of Ukraine" (Do dnia sobornosti Ukrainy) the user has the opportunity to get acquainted with some issues of such periodicals as "Ukraina", "Republyka" and "Vistnyk derzhavnykh zakoniv ta rozporiadkiv Zakhidnoi Oblasty Ukrainskoi Narodnoi Republyky" (Do dnia sobornosti Ukrainy). The presented articles of these newspapers are devoted to important events that marked the unity of our state. In particular, the newspaper "Vistnyk derzhavnykh zakoniv ta rozporiadkiv Zakhidnoi Oblasty Ukrainskoi Narodnoi Republyky" published the Resolution of the Ukrainian National Council on the Unification of the Western Ukrainian People's Republic and the Ukrainian People's Republic (Vistnyk derzhavnykh zakoniv, 1919: 1). 
In the electronic version of the newspaper "Republyka", presented on the website of TSDAVO of Ukraine (Vovk, 2016: 33), presents to the reader information about the Ukrainian-Polish armistice talks and other information about the war for the liberation of Ukraine.

In the State Archives of the Lviv region (DALO) as of 01.01.2020 in the archive are stored 5154 funds, 2671626 storage units, including 42194 photo, 6708 film, 697 sound documents. The DALO website contains the Electronic Archive section with subdivisions: Pre-Soviet Funds, Soviet Period Funds, Former Party Archive Funds, Independence Funds, Civil Status Registration Acts from 1940, Publications and the Project "Heroics" (ZUNR). The section Funds subdivisions contain a list of funds and separate case descriptions. The section Civil Registration Acts from 1940 as of August 2021 is empty. Regarding the Publications section, it contains 62 scanned different documents in three categories (DALO Publications, History of Lviv in printed editions, Printed editions for children).

The section of the Exhibition Online website is represented by 13 electronic exhibitions (76 electronic exhibitions in 2017), dedicated to both prominent political and public figures of Ukraine, as well as significant events in the establishment of Ukrainian statehood. In such electronic exhibitions, the user has access to electronic versions of individual documents and photographs that illustrate specific events. Electronic exhibitions of magazines of Ukraine of the period of liberation struggles, pre-war and interwar periods are placed in separate exhibitions (Vovk, 2016: 198).

Among these exhibitions, the user has access to an exhibition with partial publications of periodicals of the Western Ukrainian People's Republic, which provide information about the then independence and unity of the Ukrainian state - "Do 98 richnytsi Aktu zluky Ukrainskoi Narodnoi respubilky i Zakhidno-Ukrainskoi respubliky" presented by 39 documents and photographs characterizing this event. Among them are such newspapers: "Holos Kalusha" from January 11, 1919. (published articles "Istorychna podia", "Ukrainskyi parlament"); "Drohobytskyi lystok" (posted "Rezolutsii z III zizdu vid poruchnykiv sil i mist Drohobycha z 29. hrudnia 1918 r."; "Vidozva "Zhovniry!"” from January 7, 1919.); "Vistnyk derzhavnykh zakoniv ta rozporiadkiv Zakhidnoi Oblasty Ukrainskoi Narodnoi Republyky" (the act of Reunion is placed) (Do 98 richnytsi). In 2017, another thematic exhibition was posted on the site "Lystopadovyi chyn. Do 98-yi richnytsi utvorennia Zakhidno-Ukrainskoi Narodnoi respubliky", which contained 22 different documents, including: "Tymchasovyi osnovnyi zakon pro derzhavnu samostiinist ukrainskykh zemel buvshoi avstro-uhorskoi Monarkhii", published in newspaper "Stanislavivskyi Holos" of November 19, 1918, "Pereniatie vlasty na Halytskii Ukraini v ruky Ukr. Natsionalnoi Rady", published in newspaper "Stanislavivskyi Holos" of November 19, 1918 and article "Budova vlasnoi Derzhavy!", published in newspaper "Ukraina" of November 19, 1918 (Vovk, 2016: 36).

Conclusions. Digitization of archival documents not only opens archival funds for modern Ukrainian society, but also makes us realize the importance of the struggle for independence. The periodical press of the Western Ukrainian People's Republic was flooded with articles about the military actions of the Ukrainian Galician Army for the independence and unity of the state. Analysis of open electronic archival information will make you not only believe in victory, but also give additional strength and confidence in the unity of the Ukrainian people. Therefore, for the digitization of archival information, it is advisable to attract both additional funding and develop the latest methods and programs for the preservation of archival documents in electronic form.

\section{СПИСОК ВИКОРИСТАНИХ ДЖЕРЕЛ}

1. Архів старих газет URL : http://www.oldnewspapers.com.ua (дата звернення: 09.08.2021).

2. Бачинський В. Преса ЗУНР 1918-19. Над Сяном: матеріали до історії Украӥнської Галицької Армії. Вінніпег, 1978. Том 5. С. 126-141.

3. Битися чи миритися // Стрілець. 1919. Ч. 12. С. 3.

4. Від редакції // Вісник Державного Секретаріату Військових Справ. 1919. Ч. 8. С. 9.

5. Вістник державних законів та розпорядків Західної Области Української Народної Републики. 1919. Вип. 1. C. 1. URL : http://tsdavo.gov.ua/image/62944957.jpeg (дата звернення: 09.12.2016)

6. Вовк Н. Оцифровані періодичні видання Західно-Української Народної Республіки як історичне джерело. Історико-культурні студіï. Львів, 2016. № 1. С. 31-37.

7. Гаранін О. Вплив інформаційних технологій на утворення нових форм архівних джерел. Архіви Украӥни. Київ, 2013. № 6. С. 86-94.

8. До 98 річниці Акту злуки Української Народної респубілки і Західно-Української республіки URL: http://www.archivelviv.gov.ua/MATERIALS/EXHIBITIONS/DO-98-RICHNICI-AKTU-ZLUKI-UKRAJINSKOJINARODNOJI-RESPUBLIKI-I-ZAKHIDNO-UKRAJINSKOJI-RESPUBLIKI/4222/\#GALLERY/ (дата звернення: 09.12.2016). 
9. До дня Соборності України URL: http://tsdavo.gov.ua/4/webpages/62930749.html (дата звернення: 12.12.2016).

10. Листопадовий чин. До 98-ї річниці утворення Західно-Української Народної республіки URL: http://www.archivelviv.gov.ua/materials/exhibitions/listopadovii-chin-do-98-ji-richnici-utvorennja-zakhidno-ukrajinskojinarodnoji-respubliki/4042/\#gallery (дата звернення: 02.12.2016).

11. Лобузін І. Оцифрування історико-культурної спадщини: технологія та управління. Реєстрація, зберігання $i$ обробка даних. Київ, 2012. Т. 14, № 3. С. 104-114.

12. Република. 1919. Вип. 1. С. 1.

13. Ткачук П. Сухопутні війська України доби революції 1917 - 1921рр. Львів: ЛІСВ. 2009. 311 с.

14. Ukrainian Galician Army URL: https://commons.wikimedia.org/wiki/Category:Ukrainian_Galician Army? uselang=uk (дата звернення: 09.08.2021).

15. Vovk N. Archival Resources of Ukraine and Poland in the Global Information Network. Public Policy and Economic Development: Scientific and Practical Journal. Poznan-Mykolayiv, 2016. Issue 7 (11). P. 195-202.

\section{REFERENCES}

1. Arkhiv starykh hazet [Archive of old newspapers] URL: http://www.oldnewspapers.com.ua (date of application: 09.08.2021).

2. Bachyns'kyy V. Presa ZUNR 1918-19 [Press the Western Ukrainian People's Republic in 1918-19], Over Sian: materials in the history of Ukrainian Galician Army, 1978, Winnipeg, Nr. 5, p. 126-141. [in Ukrainian]

3. Strilets' [Sagittarius] 1919, Nr. 12, p. 3 [in Ukrainian].

4. Visnyk Derzhavnoho Sekretariatu Viys'kovykh Sprav [Bulletin of the State Secretariat for Military Affairs] 1919, Nr. 8, p. 9 [in Ukrainian].

5. Vistnyk derzhavnykh zakoniv ta rozporyadkiv Zakhidnoyi Oblasty Ukrayins'koyi Narodnoyi Republyky [Bulletin of state laws and regulations of the Western Region of the Ukrainian People's Republic] 1919, Nr. 1, p.1. URL: http://tsdavo.gov.ua/image/62944957.jpeg. (date of application: 09.12.2016)

6. Vovk N. Otsyfrovani periodychni vydannia Zakhidno-Ukrainskoi Narodnoi Respubliky yak istorychne dzherelo [Digitized periodicals of the Western Ukrainian People's Republic as a historical source]. Historical and cultural studies. Lviv, 2016. Nr 1. p. 31-37 [in Ukrainian].

7. Haranin O. Vplyv informatsiinykh tekhnolohii na utvorennia novykh form arkhivnykh dzherel [The impact of information technologies on the creation of new forms of archival sources]. Archives of Ukraine, 2013. Nr. 6, p. 86-94. [in Ukrainian].

8. Do 98 richnytsi Aktu zluky Ukrainskoi Narodnoi respubilky i Zakhidno-Ukrainskoi respubliky [To the 98 anniversary of the Act of Unification of the Ukrainian People Republic and the West Ukrainian Republic] URL: http://www.archivelviv. gov.ua/MATERIALS/EXHIBITIONS/DO-98-RICHNICI-AKTU-ZLUKI-UKRAJINSKOJI-NARODNOJI-RESPUBLIKII-ZAKHIDNO-UKRAJINSKOJI-RESPUBLIKI/4222/\#GALLERY/ (date of application: 09.12.2016)

9. Do dnia Sobornosti Ukrainy [Until the Day of the Unification of Ukraine] URL: http://tsdavo.gov.ua/4/ webpages/62930749.html (date of application: 12.12.2016).

10. Lystopadovyi chyn. Do 98-yi richnytsi utvorennia Zakhidno-Ukrainskoi Narodnoi respubliky [The November chyn. By the 98 th anniversary of Western Ukrainian People's Republic] URL: http://www.archivelviv.gov.ua/materials/exhibitions/listopadovii-chin-do-98-ji-richnici-utvorennja-zakhidno-ukrajinskoji-narodnoji-respubliki/4042/\#gallery

11. Lobuzin I. Otsyfruvannia istoryko-kulturnoi spadshchyny: tekhnolohiia ta upravlinnia. [The digitization of historical and cultural heritage: Technology and Management], Registration, storage and processing of data, 2012. Nr. 3, p. 104-114 [in Ukrainian].

12. Republyka [Republic] 1919. Nr. 1, p.1.

13. Tkachuk P. Sukhoputni viiska Ukrainy doby revoliutsii 1917 - 1921rr [Land Forces Ukraine time of the Revolution of 1917 - 1921], Lviv Institute of Land Forces. Lviv, 2009. 311p. [in Ukrainian].

14. Ukrainian Galician Army URL: https://commons.wikimedia.org/wiki/Category:Ukrainian_Galician_ Army? uselang=uk (date of application: 09.08.2021).

15. Vovk N. Archival Resources of Ukraine and Poland in the Global Information Network, Public Policy and Economic Development: Scientific and Practical Journal, Adam Mickiewicz University, Petro Mohyla Black Sea National University, Poznan-Mykolayiv, 2016. . Issue 7 (11). P. 195-202 